\title{
The Prosecution in Trial In Absentia Of Money Laundering Case Resulted from Conventional Case
}

\author{
Rudi Pradisetia Sudirdja* \\ DOI: https://doi.org/10.22304/pjih.v6n2.a5
}

Submitted: July 17, 2019 | Accepted: September 10, 2019

In Indonesia, the provision of in absentia in the Money Laundering Crime Law raises problems if the crime act is originally conventional crime act. Conventional crime act should be handled based on the provisions of the Indonesian Criminal Law Procedures Code. On the one hand, the Money Laundering Crime Law regulates the provisions of the court in absentia and, on the other hand, the Indonesian Criminal Law Procedures Code does not recognize trial in absentia. This study covers the issue. To be precise, it reveals the possibility of a conventional crime act that is charged with the Money Laundering Crime Law to be tried in absentia based on the principle of formal legality. In addition, it discusses the strategy of prosecution of money laundering crime act in trial in absentia for cases that are originally conventional crime act based on the principle of due process of law. This study used analytical description research specifications and the normative juridical method. The data was collected through a document study. In accordance with the approaches, the data were analyzed in qualitative-juridical manners. This study concludes several points. The first, based on the principle of legality of formal law, the implementation of trial in absentia against general criminal acts cannot be carried out. The second, based on the principle of due process of law, the prosecution strategy in trial in absentia fur such cases are that (1) the prosecution of money laundering crime and original crime must be done separately; (2) the public prosecutor must delay the transfer of original criminal acts to the court until the accused is found and presented; (3) the indictment must be prepared in a single form; (4) the indictment must draw legal facts about the original crime; and (5) the public prosecutor can prove the legal facts about the original crime in the element of 'assets resulting from the crime' in the money laundering offense.

Keywords: Judgment in Absence, Money Laundering, Prosecution

\section{Strategi Penuntutan Dalam Peradilan In Absensia Terhadap Tindak Pidana Pencucian Uang Dengan Tindak Pidana Asal Konvensional}

\begin{abstract}
Abstrak
Implementasi ketentuan in absensia dalam Undang-Undang Tindak Pidana Pencucian Uang (TPPU) menimbulkan persoalan bilamana tindak pidana pencucian uang berasal dari tindak pidana umum (konvensional) yang hukum acaranya mengikuti ketentuan KUHAP. Pada satu sisi, TPPU mengatur ketentuan peradilan in absensia, pada sisi lain tindak pidana asal tidak mengenal peradilan in absensia. Studi ini difokuskan pada persoalan tersebut. Beberapa

\footnotetext{
A functional prosecutor of special assistant of the Attorney General of the Republic of Indonesia, Jl. Sultan Hasanuddin No.1, Jakarta Selatan, Indonesia, S.H. (Universitas Pasundan), M.H. (Universitas Padjadjaran), email: rudipradisetia@gmail.com
} 
cakupan masalah dalam studi ini mencoba mengemukakan (1) apakah tindak pidana umum (konvensional) yang menjadi tindak pidana asal TPPU dapat disidangkan secara in absensia berdasarkan prinsip legalitas formal; dan (2) strategi penuntutan tindak pidana pencucian uang dalam peradilan in absensia dengan tindak pidana asal tindak pidana umum (konvensional) berdasarkan asas due process of law. Studi ini menggunakan spesifikasi penelitian deskripsi analitis. Metode pendekatan yang digunakan dalam studi ini adalah yuridis normatif. Teknik pengumpulan data melipui studi dokumen. Berdasarkan kepada metode pendekatan yang diterapkan, data yang diperoleh untuk penelitian ini dianalisis secara yuridis kualitatif. Ada beberapa simpulan yang dapat dihasilkan dari studi ini. Pertama, berdasarkan asas legalitas dalam hukum formal, implementasi peradilan in absensia terhadap tindak pidana asal tindak pidana umum (konvensional) tidak dapat dilaksanakan. Kedua, dengan berpedoman pada asas due process of law, maka strategi penuntutan in absensia dalam kondisi tersebut adalah bahwa (1) mekanisme penuntutan TPPU dan tindak pidana asal harus dilakukan secara terpisah; (2) penuntut umum harus menunda pelimpahan tindak pidana asal ke pengadilan sampai terdakwa ditemukan; (3) Surat dakwaan harus disusun dengan bentuk tunggal; (4) Dalam surat dakwaan harus tergambar fakta hukum ihwal tindak pidana asal; dan (5) Penuntut Umum dapat membuktikan fakta hukum ihwal tindak pidana asal dalam unsur "harta kekayaan hasil tindak pidana" pada delik TPPU.

Kata Kunci: Penuntutan, Peradilan in Absensia, Pencucian Uang.

\section{A. Introduction}

Money laundering crime act in Indonesia are increasingly massive. This has become one of the major problems and challenges faced by Indonesian law enforcement. The Financial Transaction Tracking and Analysis Center (PPATK -Pusat Penelusuran dan Analisis Transaksi Keuangan ${ }^{1}$ reveals that they receive no less than 68 million reports, or about 100,000 reports per day, related to money laundering. ${ }^{2}$ These reports are related to suspicious financial transactions, cash financial transactions, transactions involving providers of goods and services, cross-border money carrying, and abroad financial transaction. ${ }^{3}$

The increasingly massive practices of money laundering in Indonesia does not only originate from assets resulting from the illicit trafficking of narcotics and psychotropic drugs as in its early history ${ }^{4}$, or from corruption act that are vastly reported by mass media. The money laundering practices also originate from a

1 The PPATK is a state agency that coordinates the implementation of efforts to prevent and eradicate money laundering in Indonesia. Internationally, the PPATK is a Financial Intelligence Unit (FIU), which has the duty and the authority to receive financial transaction reports, conduct analysis of financial transaction reports, and forward the results of the analysis to law enforcement agencies.

2 Elsa Emiria Leba, "Berkejaran dengan Kelicikan Pencucian Uang", https://kompas.id/baca/polhuk/2018/12/22/berkejaran-dengan-kelicikan-pencucian-uang, accessed on January 2019.

3 Yohana Artha Uly, "PPATK: Setiap Hari Ada 100.000 Laporan Kasus Pencucian Uang", https://economy.okezone.com/read/2018/12/18/20/1992816/ppatk-setiap-hari-ada-100-000-laporan-kasuspencucian-uang, accessed on January 2019.

4 Romli Atmasasmita, Globalisasi dan Kejahatan Bisnis, Jakarta: Kecana Prenada Media Group, 2010, pp. 52-53. 
variety of original crime acts as stipulated in Article 2, Paragraph (1), of the Law Number 8 of 2010 on the Prevention and Eradication of Money Laundering Crimes (the Law of PPTPPU -Pencegahan dan Pemberantasan Tindak Pidana Pencucian Uang 2010). They include conventional crime acts that are regulated in the Indonesian Criminal Code.

The data from the Kompas Research and Development Center shows that during 2005 to 2018, there are 171 court decisions on the cases of money laundering originating from various conventional crime acts. The details and percentages are as follows. ${ }^{5}$

Figure 1. Number of Court Decisions related to Money Laundering Crime Acts

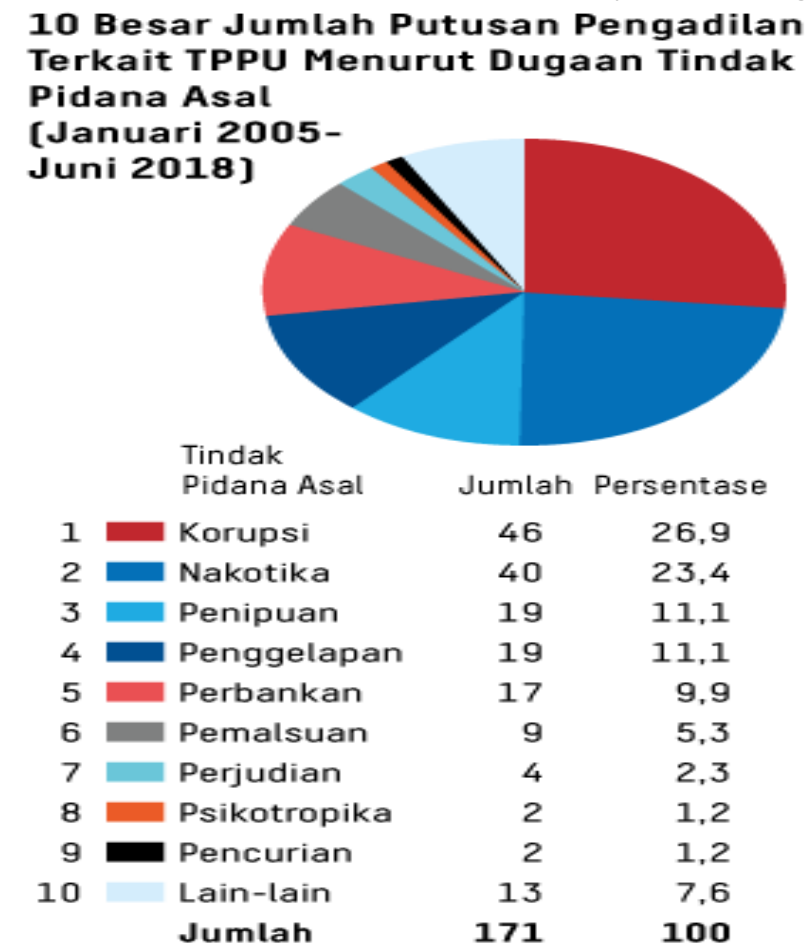

Source: Kompas Research and Development/L06, summarized from the presentation of Bentuk Praktik dan Modus Tindak Pidana Pencucian Uang (the Forms of Money Laundering Practices and Modes) and Buletin Statistik Anti Pencucian Uang dan Pencegahan Pendanaan Terorisme (the Bulletin of Anti-Money Laundering Statistics and Prevention of Terrorism Financing).

Based on the preliminary observation on the prosecution process and interviews with senior prosecutors ${ }^{6}$, one of the problems in handling the money 
laundering cases, especially those that are originally conventional crimes, is presence of defendants in trial process. Some defendants fled, hid, or were deliberately absent to avoid the legal process. Often, the cases involved the accused who were not detained or suspended. This can be understood, considering that the money laundering crime perpetrators are not ordinary people since the money laundering is in the category of white-collar crimes. ${ }^{7}$

In anticipation of the defendant's absence, Article 79, Paragraph (1), of the PPTPPU Law has regulated the provisions of trial in absentia. It means that trial and hearing of money laundering case can be carried out and decided without presence of defendant. This is a specificity (lex specialist) to the general principle (lex generalis) in Article 196, Paragraph (1), of the Criminal Procedure Code, which requires presence of defendant in the examination and conviction of criminal case trial.

Trial in absentia is an exception to the provisions of the Criminal Procedure Code. According to Manthovani and Jatna, the regulation is a breakthrough in the world of law. ${ }^{8}$ Trial in absensia arrangements of money laundering case aims to make prevention and eradication of money laundering run efficiently. ${ }^{9}$ In line with that, Kristiana explains that the practice of trial in absentia is known and implemented in Indonesia to achieve the purpose of saving assets in accordance with the principle of 'follow the money' in the money laundering offense.

Philosophically, the regulation of prosecution of trial in absentia is inseparable from the main idea of the criminalization of money laundering acts to make what in general terms is called 'the crime cannot be profitable'. ${ }^{10}$ Therefore, the priority is to confiscate assets resulting from criminal acts, rather than to act against the perpetrators. ${ }^{11}$ In other words, the main target of money laundering case trial is not aimed at perpetrators (following the suspect). It aims to save assets resulted from crime (follow the money and follow the asset). ${ }^{12}$

In practice, the prosecution process of money laundering cases in trial in absentia with original conventional cases in the forms of corruption ${ }^{13}$, terrorism ${ }^{14}$,

7 Edwin Sutherland mendefinisikan white collar crime sebagai: a violation of criminal law by the person of the upper socio-economic class in the course of his occupational activities. See Edwin H. Sutherland, White Collar Crime, Binghamton: Yale University, 1983, p. 7.

8 Reda Manthovani, R. Narendra Jatna, Rezim Anti Pencucian Uang dan Perolehan Hasil Kejahatan Indonesia, Jakarta: Malibu, 2012, p. 90.

9 Marwan Effendy, Peradilan In Absentia dan Koneksitas, Jakarta: Timpani Publishing, 2010, p. 20.

10 Chairul Huda, Expert Opinion, in the Prosecutor's Register Number: PDM- 276/CKR/05/2017 on October 19, 2017, p. 164.

11 Reda Manthovani, R. Narendra Jatna, op.cit., p. 27.

12 Ibid.

13 Article 38, Paragraph (1), of the Law Number 31 of 1999 on Eradication of Corruption Acts as amended by the Law Number 20 of 2001 on the Amendment to the Law Number 31 of 1999 on Eradication of Corruption (the PTPK Law).

14 Article 35, Paragraph (1), of the Law Number 15 of 2003 on the Establishment of Government Regulations in lieu of the Law Number 1 of 2002 on the Eradication of Terrorism Criminal Acts into Laws, as amended by the Law Number 5 of 2018 on the Amendment to the Law Number 15 of 2003 on the Establishment of 
fishery crime ${ }^{15}$, and forestry ${ }^{16}$ crime does not cause procedural problems and debates. This is because the law governing the types of crime acts also regulates the provisions regarding trial in absentia. Therefore, the prosecution process for such cases can be done simultaneously. Public Prosecutor can delegate both money laundering and original cases to the court in a cumulative indictment. Likewise, for the purposes of the evidentiary process, public prosecutor can place the original criminal offense on the first and the money laundering on the second indictment. Therefore, the original criminal offense can be proven in advance from the money laundering case.

It is evidenced in the case of the Century Bank with the defendants Hesham Al Warraq and Rafat Ali Rizvi, who allegedly embezzled more than US \$300 million, were charged with corruption and money laundering. ${ }^{17}$ The trial of the defendants was carried out in absentia. The public prosecutor submitted both corruption and money laundering cases together in a cumulative indictment. In the verification process, the original crime case is proven before the money laundering case.

The case is different from the handling of money laundering originated from conventional crime that is regulated in the Criminal Code. The handling of criminal cases of origin refers to the provisions of the Criminal Procedure Code. On the other hand, the Criminal Procedure Code as a formal law for this type of crime does not recognize trial in absentia. ${ }^{18}$ Therefore, the handling of money laundering cases with criminal acts originating from general conventional criminal acts in trial in absentia raises problems. On the one hand, the procedural law of the money laundering allows the process of trial in absentia. On the other hand, the criminal procedural law for conventional criminal acts does not regulate the provisions for trial in absentia.

Such problem happened in the case ${ }^{19}$ of the defendant Hendra Widjaja at the Bekasi District Court. The trial is in absentia. The defendant, the Vice President Director of PT. Showa Indonesia Manufacturing, was suspected of committing embezzlement in violation of Article 374 of the Indonesian Criminal Code and committing money laundering. The public prosecutor had trouble in applying the provisions of trial in absentia because the money laundering procedural law

Government Regulation in Lieu of the Law Number 1 of on the Eradication of the Criminal Acts of Terrorism into Laws (the Law on Terrorism).

15 Article 79 of the Law Number 31 of 2004 on the Fisheries as amended by the Law Number 45 of 2009 on the Amendment to the Law Number 31 of 2004 on Fisheries (Fisheries Law).

16 Article 51 of the Law Number 18 of 2013 on the Prevention and the Eradication of Forest Destruction

17 The panel of judges sentenced each prison sentence for fifteen years, a replacement money of Rp3,115,889,000,000.00 (three trillion one hundred fifteen billion eight hundred eighty nine million rupiah) and a fine of Rp15,000,000,000, 00 (fifteen billion rupiah). See Central Jakarta District Court Decision Number: 339/PID.B/2010/PN.JKT.PST, Jakarta, 2010, p. 256.

18 Article 196, Paragraph (1), or the Criminal Procedural Law.

19 Based on the Order of the Head of the Bekasi District Prosecutor Office Regarding the Appointment of a Public Prosecutor to Resolve Criminal Case Number: PRINT.1119/O.2.35/Euh.2/3/2017 dated March 23, 2018, Members of the Public Prosecution Team consisted of Sandhy Handika, Satria Lerino, Mylandi Susana, and Rudi Pradisetia Sudirdja. 
regulates the provision of trial in absentia but the Criminal Procedure Code to process criminal acts under the provisions of Article 374 of the Criminal Code does not regulate trial in absentia. Therefore, problems arise in practice regarding the prosecution mechanism in the case without the presence of the defendant. The prosecutor faced difficulties to determine whether the prosecutions of the money laundering and the original crime can be carried out simultaneously in one indictment. The Article 196, Paragraph (1), of the Criminal Procedure Code does not regulate the provision of trial in absentia for conventional criminal acts. The prosecutor actually had another way, for example, the prosecution was carried out separately by simply prosecuting the money laundering and delaying the prosecution of the original criminal act.

Furthermore, it is interesting to study the evidentiary technique of the public prosecutor if the public prosecutor only indicted the money laundering case and postponed the prosecution of the original criminal act. In addition, it is interesting to observe the evidentiary technique for the element of "assets resulting from criminal offenses" as a core part of money laundering's delicts, considering that the original criminal act had not been proven or, at least, proven simultaneously with the money laundering in one cumulative indictment. Finally, the provision of Article 69 of the 2010 PPTPPU Law states, "Untuk dapat dilakukan penyidikan, penuntutan, dan pemeriksaan di sidang pengadilan terhadap tindak pidana Pencucian Uang tidak wajib dibuktikan terlebih dahulu tindak pidana asalnya" [To be able to carry out investigations, prosecutions, and examinations in court of trial for Money Laundering offenses must not be proven before the original criminal offense]. It is interesting to study whether, in such cases, the provision can be applied.

In practice, this condition certainly becomes a problem in resolving money laundering cases with conventional criminal offenses to be trialed in absentia. That is because, up to now, there are no legal provisions that govern such conditions. In fact, the existence of procedural law is absolute to provide certainty and as a basis for law enforcement officers in carrying out their duties and authorities.

Based on the objective reality, this study aims to perform a legal analysis, which is focused on the strategy to prosecute money laundering in trial in absentia with originally conventional crime. To be precise, this study reveals ways to bring general crime acts from the money laundering before trial in absentia based on formal legality ${ }^{20}$ and finds out the strategy of money laundering prosecution in trial

20 The principle of formal legality or the principle of legality in criminal procedural law is a principle that asserts that all government actions must be based on legal and written legislation. Andi Hamzah says that the principle of legality is regulated in Article 3 of the Criminal Procedure Code, which states 'Judicial proceedings are based on this law.' See Andi Hamzah, Hukum Acara Pidana Indonesia, Jakarta: Sinar Grafika, 2009, p. 11 More precisely, according to Andi Hamzah, with the principle of legality, the way to prosecute in criminal proceedings in a country must be carried out based on the law. See Andi Hamzah, Pre-Trial Justice Discretionary Justice Dalam KUHAP Berbagai Negara, Jakarta: Sinar Grafika, 2015, p. 4. 
in absentia with criminal acts originating from conventional crime act based on the principle of due process of law.

\section{B. The Application of the Trial in Absentia on the Conventional Crime Case that is the Origin of Money Laundering Case based on the Principle of Formal Legality}

With regard to the efforts of saving assets, prosecution of money laundering case is connected to its original crime. The original crime is a conventional crime that results wealth or benefit. In this case, the money laundering is a follow-up crime from the previous crime. Therefore, the money laundering law denounces only the follow-up act, which is act committed after the original crime. However, even though money laundering is a follow-up crime, it must be understood as a separate crime. It must also be understood that there is no money laundering without the original crime act. ${ }^{21}$

The crime acts of money laundering origins are regulated in Article 2 of the 2010 PPTPPU Law. They are (1) corruption, (2) bribery, (3) narcotics, (4) psychotropic substances, (5) smuggling labors, (6) smuggling migrants, (7) the banking sector crimes, (8) the capital market sector crimes, (9) the insurance field crimes, (10) in customs crime, (11) excise crimes, (12) trafficking persons, (13) Trafficking illegal weapons, (14) terrorism, (15) abduction, (16) theft, (17) embezzlement, (18) fraud, (19) counterfeiting money, (20) gambling, (21) prostitution, (22) the taxation field crimes, (23) the forestry sector crimes, (24) environmental field crimes, (25) maritime affairs and fisheries crimes, and (26) other offenses. The offences are threatened with imprisonment of four (4) years or more.

Based on Article 2 of the 2010 PPTPPU Law, the study classifies money laundering crime into two categories. The first covers specific criminal offenses, namely criminal acts that are formulated separately in the provisions of special laws. $^{22}$ The second is general criminal acts, namely various criminal acts as regulated in the Criminal Code. The forms of general criminal acts that are regulated as money laundering origins include kidnapping, theft, embezzlement, fraud, counterfeiting money, gambling, and prostitution. The offenses are threatened with imprisonment of four (4) years or more. They are regulated in the Criminal Code.

To discuss the problem, this study examined the possibility of the application of trial in absentia to money laundering cases with originally conventional crime acts. The analysis is based on the principle of formal legality in criminal procedural law. This principle asserts that all government actions must be based on legal and written legislation. Every administrative action or policy must be based on rules or

\footnotetext{
21 Yenti Garnasih, Penegakan Anti Pencucian Uang dan Permasalahannya di Indonesia, Jakarta: PT Raja Grafindo Persada, 2015, p. 8.

22 Sudarto, Kapita Selekta Hukum Pidana, Bandung: PT. Alumni, 2006, p. 64.
} 
procedures (regels). ${ }^{23}$ This principle is a guideline for law enforcement officers so that every action taken is directed in accordance with the provisions of the legislation.

In Indonesian Criminal Procedure Law, the principle of legality is found in letter a of the Criminal Procedure Code. It states that the government has an obligation to uphold the law with no exception. Indonesia recognizes the principle of legality as a logical consequence since Indonesia adopts the concept of the rule of law. In a state of law, all forms of action of both citizens and government, including its apparatuses, must be in accordance with applicable law.

As an implementation of these considerations, further legality arrangements can be found in Article 3 of the Criminal Procedure Code. It states, "Peradilan dijalankan berdasarkan undang-undang ini" [The judiciary is carried out based on this law]. That is, the criminal justice system organs in carrying out their duties and authorities must be in accordance with the procedural law as regulated by the Criminal Procedure Code. Likewise, the procedure and trial mechanism must be held based on the formal law.

The Criminal Procedure Code is the main guideline for the implementation of the judicial process in Indonesia. Starting from the implementation of preliminary investigation, full investigation, prosecution, trial, to legal remedy, the process has regulated rights and obligations, as well as the legal mechanism, of parties. Therefore, in principle, the mechanism of proceedings for the resolution of various criminal acts, both general and specific criminal offenses, refers to the Criminal Procedure Code. The difference lies in the special procedural law for the special criminal law that is different from the Criminal Procedure Code. One of them is trial in absentia.

Furthermore, with regard to the implementation of trial in absentia on general crime act, which is an original of money laundering act, there is no clear regulation up to now. Article 68 of the 2010 PPTPPU Law only formulates that "penyidikan, penuntutan, dan pemeriksaan di sidang pengadilan serta pelaksanaan putusan yang telah memperoleh kekuatan hukum tetap terhadap tindak pidana sebagaimana dimaksud dalam Undang-Undang ini dilakukan sesuai dengan ketentuan peraturan perundang-undangan, kecuali ditentukan lain dalam UndangUndang ini" [investigation, prosecution, and examinations in court proceedings and the implementation of decisions that have obtained permanent legal force over a crime act as referred to in this Law are carried out in accordance with statutory provisions, unless it is otherwise stipulated by this law].

This study is in the view that the provision implies the judicial process of an original crime still refers to the general laws and regulations, in this case the Criminal Procedure Code. However, if the 2010 PPTPPU Law determines otherwise,

23 Jimly Asshiddiqie, "Prinsip Pokok Negara Hukum," http://www.jimly.com/pemikiran/view/11, accessed on February 2019. 
then the process refers to the 2010 PPTPPU Law because the 2010 PPTPPU Law does not regulate the trial in absentia for original criminal investigation procedures. Therefore, the examination mechanism must refer to the Criminal Procedure Code.

Furthermore, the Criminal Procedure Code as a formal law obliges defendants to appear in court of trial. Article 196, Paragraph (1), of the Criminal Procedure Code states that "Pengadilan memutus perkara dengan hadirnya terdakwa kecuali dalam hal undang-undang ini menentukan lain" [The court decides the case with the presence of the defendant except in the event that this law determines otherwise]. In other words, trial in absentia justice can only be applied to crime acts that are expressly regulated and allowed by law.

Likewise, Article 12, Paragraph (1), of the Law Number 48 of 2009 on Judicial Power states, "pengadilan memeriksa, mengadili dan memutus perkara dengan kehadiran terdakwa, kecuali undang-undang menentukan lain" [the court examines, hears, and decides cases in the presence of defendant, unless the law determines otherwise]. That is, the trial in absentia of crime may only be carried out for certain crime acts, which by law are strictly regulated and permitted. The arrangements of trial in absentia are not covered by regulations in the PPTPPU Law.

Furthermore, in money laundering theory, there is a separation between original crime and money laundering crime. Both are two different crime acts. According to Arief, original crime is offense that results in crime proceeds ${ }^{24}$, while money laundering is a follow-up offense of the crime proceeds. Therefore, the money laundering and the original crimes are offenses and each of which stands alone as a separate crime. ${ }^{25}$ The regulation of trial in absentia in the 2002/2003 PPTPPU and the 2010 PPTPU Law for cases of money laundering does not automatically apply to the original crime acts because both are criminal acts that each stand alone.

Article 79 of the PPTPPU Law 2010 regulates the provision of trial in absentia. It reads, "Dalam hal terdakwa telah dipanggil secara sah dan patut tidak hadir di sidang pengadilan tanpa alasan yang sah, perkara dapat diperiksa dan diputus tanpa hadirnya terdakwa" [In the case that defendant has been legally and orderly called and does not present in court without a valid reason, the case can be examined and decided without the presence of the defendant]. Article 36, Paragraph (1) of the 2002/2003 PPTPPU Law reads, "dalam hal terdakwa telah dipanggil 3 (tiga) kali secara sah sesuai dengan ketentuan peraturan perundangundangan yang berlaku tidak hadir, Majelis Hakim dengan putusan sela dapat meneruskan pemeriksaan dengan tanpa kehadiran terdakwa" [in case defendant has been legally called 3 (three) times in accordance with the provisions of the applicable laws and regulations, is absent, the Panel of Judges with an interim decision can proceed with the examination without the presence of the

\footnotetext{
24 Barda Nawawi Arief, Kapita Selekta Hukum Pidana tentang Sistem Peradilan Pidana Terpadu (integrated criminal justice system), Semarang: Badan Penerbit UNDIP, 2006, p. 19.

25 Yenti Garnasih, op.cit., p. 8.
} 
defendant]. This article is of the opinion that the provision is only valid for the case of money laundering. It is not automatically effective for the handling of original criminal offenses. This is because the exclusion of "the principle of the presence of defendant in trial" is not stated explicitly also valid for crime act originating money laundering. In line with this, according to Hiariej, deviations from a legal principle can only be done when such deviations are expressly stated in law. ${ }^{26}$ As long as there is no explicit statement, the legal principle must be obeyed and is not to be violated.

In addition, the absence of the rules also does not allow law enforcers to conduct trial in absentia on original crime acts. Especially, case of original crime act, which by the event is not permitted to be tried in absentia, such as a general criminal offense in the Criminal Code that the trial process refers to the Criminal Procedure Code. In the principle of legality, law enforcement officials are not allowed to act outside the law, or undue to law, or undue process.

The prohibition of the undue process is based on the principle of respect for human rights, which is the forerunner to the formation of the Criminal Procedural Law. The whole set of justice process mechanisms, including the rights and obligations of each party, as well as the authority granted to law enforcement officials must be regulated fully in procedural law. This is intended so no abuse of authority or power by the law enforcement officers.

Based on the history, the principle of legality was born in opposition to the absolute power of kings, where many of these powers led to arbitrariness. The initiator of the principle, Paul Johan Anslem von Feuerbach (1775-1833), tried to formulate a principle that can limit the authority of ruler, so that state does not indiscriminate prosecutions of its citizens especially for acts that are not previously regulated in the provisions of the law. Simply, there are three basic principles of legality in formal law: lex scripta, lex stricta, and lex certa.

First, the lex scripta, means that legality relies on written law. ${ }^{27}$ In the context of this discussion, the provisions of trial in absentia for criminal acts as long as they are not explicitly regulated in the PPTPPU Law. In fact, a deviation from the principle of law, including the principle of "the presence of the accused in court", can only be done based on written law. Considering that original crime act is part of the Criminal Procedure Code, while the Criminal Procedure Code does not recognize trial in absentia, therefore, based on the lex scripta principle, the application of trial in absentia for original crime act of money laundering which cannot be carried out.

26 Expert Statement of Eddy OS Hiariej at the Constitutional Court Trial in the Dispute Results of the 2019 Presidential Election Results.

27 Shidarta, "Asas Legalitas", https://business-law.binus.ac.id/2016/02/02/asas-legalitas/, accessed on June 2019. 
Second, the lex stricta means that the written law must be interpreted fixedly. ${ }^{28}$ In connection with this discussion, since the PPTPPU Law does not mention expressively the provision of trial in absentia justice for original crime act of money laundering case, according to the lex stricta principle, it is not permissible to interpret the provisions in the procedural law. Provision regarding trial in absentia as regulated in Article 36, Paragraph (1), of the 2002/2003 PPTPPU Law and Article 79 of the 2010 PPTPU Law may not be interpreted other than those written in the law. This has the consequence that the provision of trial in absentia in the PPTPPU Law cannot be applied to general criminal offenses, which is conducted by the Criminal Code.

Third, the concept of lex certa emphasizes the importance of certainty as the earliest legal goal to be achieved before people discuss other values such as justice and expediency. ${ }^{29}$ The application of trial in absentia to original case of money laundering that fall into the category of general crime acts under the pretext of efficiency and to facilitate handling of money laundering case, as well as victim's justice, is inappropriate. This is because based on the principle of formal legality that legal certainty in the implementation of procedural law is primary. Without legal certainty in the implementation of the judicial process, it would not be possible to realize justice or even benefit the litigants. In other words, justice and benefits for parties can only be found through the implementation of procedural law in a consistent and consistent manner in accordance with the provisions written in the law. In addition, based on the principle of legality, defendant has the same position that must be protected by law, known as the principle of equal protection on the law. Therefore, every law enforcement officer in making decisions must consider the principle of legal protection of defendant. It is not justified to take actions that can harm defendant without a clear legal basis. The decision was made so that all parties, both defendants and victims, including law enforcement officials, receive the same "justice treatment" under the law. This is in accordance with the principle of equal justice under the law because of the rule of law, in accordance with Article 1, Paragraph (3), of the 1945 Constitution.

Another thing to point is that Criminal Procedure Code requires restriction of individual freedom. In procedural law, law enforcement officers have various authorities of coercive acts such as arrest, detention, search, and seizure. These coercive acts are certainly contrary to the principle of human rights but these actions are part of the implementation of the power of law enforcement and are regulated in writing in the law. Therefore, these actions are justified as long as they are carried out in accordance with applicable procedures.

Article 3 of the Criminal Procedure Code states that "Peradilan dijalankan berdasarkan undang-undang ini" (Judiciary is carried out based on this law). This 
means that law enforcers in carrying out justice must be based on the Criminal Procedure Code. They cannot take actions outside of the law. The principle of legality in procedural law is more stringent than the principle of legality in material criminal law. Only law can carry out the criminal procedure law. The provisions under the law cannot regulate it. This is an embodiment of the principle of division of state power, which mandates checks and balances in the exercise of power. The House of Representatives make the law based on their capacity of a legislative body, a representation of people. The executive body, without the legislative body, makes the regulations below it, except the regional regulations. Therefore, the procedure of procedural law should only be carried out based on the law, as a limitation so that the procedural law is not made arbitrarily only for the benefit of law enforcement officials but it must also respect the human rights principle of defendant or victim.

If the trial in absentia is applied to original crime case originating money laundering case, whereas there is no written provision that justifies this, then public prosecutor has no legal basis according to law. That action is of course contrary to the principle of human rights and the principle of protection of the rights of the defendant, given the potential of arbitrary abuse.

Money laundering cases has differences compared to other specific crime acts. Other specific crime acts, such as corruption, forestry crime, fishery crime, terrorism is regulated together with their respective original crimes to be possible to be trialed in absentia. Since the provisions of the cases also expressly regulates trial in absentia, then if such crimes are the original cases of money laundering cases, their trials can also be held simultaneously in one case and be trialed in absentia. Based on the principle of formal legality, the implementation of trial in absentia on conventional crime case originating money laundering is not possible, bearing in mind that the money laundering law does not explicitly regulate it.

\section{Strategy of Prosecution in Trial in Absentia for Money Laundering Case Originating from Conventional Crime Acts Based on the Principle of Due Process of Law}

The previous section reveals that the implementation of trial in absentia for money laundering case originating from conventional crime acts is not possible according to the Criminal Code based on the principle of formal legality. Consequently, Public Prosecutor must deal with prosecution mechanism, form of indictment, proving elements of the money laundering, etc. To overcome these problems, this study analyzed the process of handling the case of the defendant Hendra Widjaja, SE in the Bekasi District Prosecutor's Office. The analysis included the principle of due process of law, which requires a fair and proper judicial process. This principle was formulated to protect the rights of Indonesian citizens who involves in criminal 
proceedings. Thus, criminal law enforcement can be done fairly and properly because it is based on humanity values. ${ }^{30}$

\section{Urgency of the Implementation of Prosecution in Absence of Defendant Hendra Widjaja}

Prior to the discussion, this article explains the background of the case and its urgency and consideration to be trialed in absentia. This description is obtained from observation as the prosecutor who handled a quo case as well as the interview with Sandhy Handika, Head of the Public Crimes Section of the Bekasi District Prosecutor's Office.

The case involving Hendra Widjaja began in 2012. The Prosecutor from the Bekasi District General Prosecutor Office received the suspect and the evidence (second phase investigation) from the Jakarta Police on May 2, 2012. Furthermore, on May 14, 2012, the public prosecutor handed the case to the Bekasi District Court. The Head of the Bekasi District Court appoints the panel of judges who trialed the case. Subsequently, the panel of judges determined the day of the hearing. During the trial, the defendant through his lawyer applied for a permit to seek treatment, the panel of judges granted the permit. Unfortunately, at the time of treatment, the defendant ran away. The public prosecutor succeeded to rearrest the defendant. The trial continued, the defendant's lawyer submitted an exception. Then, the panel of judges granted the exception from the defendant's legal counsel.

In 2013, the case was brought again to trial. The lawyer re-submitted an exception. The panel of judges received the exception. The public prosecutor filed resistance to the High Court. The Panel of Judges at the High Court ruled that the interim decision in the Bekasi District Court was correct. Furthermore, this case stalled until 2017.

In 2017, the public prosecutor handed an a quo case back to the court. For this purpose, the public prosecutor changed the indictment. The changes were carried out with regard to the judicial mechanism that would be submitted by the public prosecutor to the judges, namely the trial in absence. One consideration of the request is that the defendant can be tried in absentia because the defendant is not known to exist. The public prosecutor had taken various steps and efforts to bring the defendant but the defendant was not found.

According to Reda Manthovani, the General Assistant of the General Attorney, the initiative of the Bekasi District Public Prosecutor to submit the request of a trial in absentia is a legal breakthrough. Bearing in mind, the case has been postponed since 2012 and is one of the stuck cases at the Prosecutor's Office. ${ }^{31}$ In addition, on

\footnotetext{
Yesmil Anwar, Adang, Sistem Peradilan Pidana: Konsep, Komponen, dan Pelaksanaan dalam Penegakan Hukum di Indonesia, Bandung: Widya Padjadjaran, 2009, p. 42

31 interview with Reda Manthovani Manthovani, General Assistant of the Attorney General of the Republic of Indonesia, on April 5, 2019, took place at the Indonesian Attorney General's Office.
} 
the philosophical basis, the main target of the money laundering is to follow the money, not to follow the suspect. Therefore, the implementation of trial in absentia in the $a$ quo case is appropriate.

The case of Hendra Widjaja must be resolved immediately since it is closely related to the interests of PT SIM as the victim. If the case was not resolved, PT SIM could be a double victim. First, it became the victim of an act committed by the defendant. Second, it became a victim of the criminal justice system since the case had not been prosecuted for years. In addition, the trial in absentia is a reflection that law enforcers must not be inferior to criminal's cunning. Law enforcers must have creative ways that are legal to be able to bring perpetrators of crime to the court. There must not be an assumption that the perpetrators cannot be brought before the law by running away, especially white-collar crimes. ${ }^{32}$

Therefore, the trial in absentia arrangements must also be interpreted that the state protects the interests of community/victim and a positive contribution to systematic and integral law enforcement. It is not merely prioritizing the approach of follow the suspect but also combining it with the approaches of follow the money and follow the asset. This holistic law enforcement is also a warning for perpetrators of crimes that there is no safe haven for results of their crimes.

\section{Prosecution Mechanism and Form of Indictment}

The defendant, Hendra Widjaja, has embezzled PT Showa Indonesia Manufacturing (PT SIM) for Rp138,202,720,550.00 (one hundred thirty-eight billion two hundred two million seven hundred twenty thousand five hundred fifty Rupiahs). The embezzlement was carried out when he was serving as the Vice President of PT SIM. After that, the defendant has used some of the assets to pay or to buy a number of lands, properties, and motor vehicles with the intention to conceal or disguise the assets. His activities were reasonably suspected to be the results of his embezzlement.

In preparing the indictment, the form must be adjusted to the case. According to Yusuf, the results of the case matrix will usually be very helpful to the public prosecutor in determining the form of indictment for a case. It is important to understand that, in general, money laundering must be viewed as an independent crime that is distinguished from original crime although they are closely related. ${ }^{33}$

In the a quo case indictments in 2012 and 2013, the public prosecutor compiled cumulative charges. There were charges of crimes originating from "embezzlement in the office", in addition to the money laundering indictment. However, in 2017, the public prosecutor changed the indictment by only indicting the money laundering. The Public Prosecutor made an indictment in the form of a single

\footnotetext{
interview with Sandhy Handika, loc.cit.

33 Muhammad Yusuf, Kapita Selekta TPPU: Kumpulan Pembahasan Mengenai Isu-Isu Terkini dan Menarik, Jakarta: PPATK, 2016, p. 193.
} 
indictment. ${ }^{34}$ It included only the money laundering without indicting the original crime, even though the original criminal act was clearly known and even filed in the same file during the investigation stage. Articles charged to Hendra Widjaja are as follows.

\section{Kesatu:}

Perbuatan Terdakwa tersebut adalah tindak pidana sebagaimana diatur dan diancam pidana pada Pasal 3 ayat (1) huruf $b$ UndangUndang Nomor 15 Tahun 2002 tentang Tindak Pidana Pencucian Uang, sebagaimana telah diubah dengan Undang-Undang Nomor 25 Tahun 2003 tentang Perubahan Undang-undang No.15 tahun 2002 tentang Tindak Pidana Pencucian Uang jo Pasal 65 ayat (1) KUHP jo Pasal 95 Undang-Undang Nomor 8 Tahun 2010 tentang Pencegahan dan Pemberantasan Tindak Pidana Pencucian Uang.

\section{dan}

\section{Kedua:}

Perbuatan Terdakwa tersebut adalah tindak pidana sebagaimana diatur dan diancam pidana pada Pasal 3 ayat (1) huruf c UndangUndang Nomor 15 Tahun 2002 tentang Tindak Pidana Pencucian Uang, sebagaimana telah diubah dengan Undang-Undang Nomor 25 Tahun 2003 tentang Perubahan Undang-undang No.15 tahun 2002 tentang Tindak Pidana Pencucian Uang jo Pasal 65 ayat (1) KUHP jo Pasal 95 Undang-Undang Nomor 8 Tahun 2010 tentang Pencegahan dan Pemberantasan Tindak Pidana Pencucian Uang.

[First:

The Defendant's actions are criminal acts that are regulated and threatened with criminal sanctions in Article 3, Paragraph (1), letter b, of the Law Number 15 of 2002 on Money Laundering, as amended by the Law Number 25 of 2003 on the Amendment to the Law Number 15 of 2002 on Crime Acts of Money Laundering, in conjunction with Article 65, Paragraph (1), of the Criminal Code, in conjunction with Article 95 of the Law Number 8 of 2010 on the Prevention and the Eradication of Money Laundering Crimes.

Second:

and

The Defendant's actions are criminal acts that are regulated and threatened with criminal sanctions in Article 3, Paragraph (1), letter c, of the Law Number 15 of 2002 on Money Laundering, as amended by the Law Number 25 of 2003 on the Amendment to the Law Number 15 of 2002 on the Crime Acts of Money Laundering, in conjunction with

34 According to the Circular of the Attorney General of the Republic of Indonesia Number: SE-004/J.A/11/1993 on the Making of Indictment (SEJA Indictment), in a single indictment, only one criminal offense is charged because there is no possibility to propose alternatives or substitute charges 
Article 65, Paragraph (1), of the Criminal Code, in conjunction with Article 95 of the Law Number 8 of 2010 on the Prevention and the Eradication of Money Laundering Crimes.]

Judging from the form of the indictment, which only includes the money laundering articles without indicting the original criminal offense (Article 374 of the Criminal Code), it means that the public prosecutor splits the case file and separate the money laundering and the original crime acts.

In terms of regulation, for the time being, a separate examination between the money laundering and the original crime and the making of a single indictment for the money laundering only in the case of the defendant Hendra Widjaja is the right decision. This is because there are no regulations that allow "criminal offenses" from money laundering can be trialed in absentia together with the money laundering case.

The PPTPPU Law has not covered this problem. If the Public Prosecutor insists to keep combining the two cases, it will result in the invalid judicial process for the original crime. This is because the Criminal Procedure Code adheres to the principle of legality. The law enforcement officers, in carrying out the law, must be in accordance with the provisions of the law. They may not act outside the law and outside requirements. Article 3 of the Criminal Procedure Code confirms that judgment must be carried out according to the provisions of the code.

In line with this, Handika says that the amendment to the 2017 indictment, by only indicting the money laundering, was carried out because the Criminal Procedure Law does not allow the application of trial in absentia for general conventional crime acts like embezzlement. Therefore, the single indictment in a trial in absentia for cases of money laundering and conventional crime acts cannot be accepted formally.

This study is of the opinion that is similar to steps taken by the public prosecutor to indict the money laundering without the original crime. This is appropriate because if the case is forced into one criminal investigation process, it has the potential to cause violations of the due process of law, which mandates that the judicial process must be carried out fairly and properly. ${ }^{35}$ The violation is due to the procedural law for general criminal acts that does not recognize trial in absentia. The Criminal Procedure Code requires the defendant to attend court proceedings based on Article 196, Paragraph (1), of the Criminal Procedure Code in conjunction with Article 12, Paragraph (1), of the Law Number 48 of 2009.

For this reason, before the case is accepted, the public prosecutor copied the money laundering case file to the original investigator, in this case the Metro Jaya Regional Police. It is to anticipate the finding of the defendant so that the Public

35 According to Sandhy Handika, this was done in good faith to respect the principles of law and to prevent abuse of power in the implementation of law enforcement. 
Prosecutor could also delegate the original criminal case to the Court based on the case file.

Furthermore, according to Article 69 of the 2010 PPTPPU Law, investigations, prosecutions, and examinations in a court of law against a money laundering are not required to be proven prior to the original crime. The provisions of Article 69 can also be used as one of the basis and guidelines for prosecuting moneylaundering cases with criminal offenses as long as the general criminal offense is in absentia. With reference to these provisions, the public prosecutor can separate the money laundering judicial process from the original crime. The public prosecutor may have first the defendant in the trial in absentia with a single money laundering indictment and delay the prosecution of the original crime act. This is important to be done as one of respect for the principle of due process of law as a set of procedures required by law as a universally valid standard of procedure. ${ }^{36}$ Separation of money laundering case and criminal offense case is also carried out to avoid an "arbitrary process" or "arbitrary process based solely on law enforcement powers". These principles were formulated to protect the rights of Indonesian citizens dealing with criminal proceedings. Thus, criminal law enforcement can be done fairly and properly ${ }^{37}$ because it is based on human values based on clear written regulations, not based on the tastes of law enforcement.

\section{Technique for Preparing Indictment}

In compiling a single money laundering indictment without original criminal offenses, public prosecutor must continue to clearly describe the origin of the "assets obtained from criminal acts". Although the original criminal act was not indicted in the description of the money laundering, it must still be drawn and derived from what crime the assets were. The clarity is necessary because it is related to the interests of proof. In the claim letter, the legal facts will be proven by the Public Prosecutor to fulfill the element of "assets resulting from criminal acts".

\section{Prohibition of the Defendant's Lawyer to Attend the Trial in Absentia}

The money laundering case trial raises various dynamics in its handling. One of them is about the position of legal counsel present at the trial to represent the defendant. In the case of Hendra Widjaja, a lawyer claimed to represent the defendant. The legal advisor asked the Panel of Judges to be allowed to sit on behalf of the defendant in the a quo trial. At that time, however, the public prosecutor objected and stated that the existence of the lawyer was invalid because the lawyer represented someone who had deliberately hidden and did not present at the hearing. In a criminal case, the role or position of a lawyer is to assist a defendant, not to represent as in civil cases. Therefore, the defendant has an

Eddy O. S. Hiariej, Teori \& Hukum Pembuktian, Jakarta: Erlangga, 2012, p. 30.

Yesmil Anwar, Adang, loc.cit. 
obligation to be present at the trial as mandated by the applicable procedural law in Indonesia.

The steps taken by the public prosecutor are correct. This is in accordance with the Circular of the Chief of Supreme Court Number 6 of 1998 on Legal Counsels or Lawyers Receiving Power of Attorney/Convicted In Absentia. In the circular, it was explained that if there were lawyer who received mandate from a defendant who was not present at the trial, even though the lawyer had been properly summoned, the judge must refuse or not serve the lawyer. This is based on the consideration of the defendant who was not present at the hearing but gave the mandate to the lawyer, it should be suspected that the defendant did not want to attend with certain purposes that benefit the defendant but could otherwise hinder the proceedings of the court.

\section{Money Laundering Verification Technique}

There is still a disagreement about the verification of money laundering. The disagreement covers the correlation of money laundering and original crime case. In fact, Article 69 of the 2010 PPTPPU Law has been strengthened by the Decision of the Constitutional Court Number 77/PUU-XII/2014 related to the Application for Judicial Review of Article 69 of the 2010 PPTPPU Law filed by R.J Soehandoyo. In the ruling, the Constitutional Court states as follows. ${ }^{38}$

"tidak perlu dibuktikan terlebih dahulu "pidana asal" untuk dapat dilakukan penyidikan, penuntutan dan pemeriksaan di sidang pengadilan dalam perkara TPPU. Namun demikian, sebagai follow up crime, untuk melakukan penyidikan, penuntutan, dan pemeriksaan dalam perkara TPPU tetap harus didahului dengan adanya tindak pidana asal. Jadi frasa "tidak wajib dibuktikan terlebih dahulu" bukan berarti tidak perlu dibuktikan sama sekali, namun TPPU tidak perlu menunggu lama sampai perkara pidana asalnya diputus atau telah memperoleh kekuatan hukum tetap."

[It is not necessary to prove original crime before investigation, prosecution, and examination can be conducted at a court hearing for a money laundering case. However, as a follow-up crime, the investigation, prosecution, and examination for money laundering cases must still be preceded by an original crime. Therefore, the phrase "does not have to be proven first" does not mean that it does not need to be proven at all, but the money laundering does not need to wait long until the original criminal case is decided or has obtained permanent legal force.]

38 Judges' Considerations in Court Decisions on Decision Number 77/PUU-XII/2014. 
According to Huda, ${ }^{39}$ there are three groups of opinions related to the controversy whether the original crime act must be proven before the money laundering crime. The first opinion states that the original crime must be proven first until the judge's decision has permanent legal force, then the money laundering can be proven. The second is the opinion that money laundering case does not have to be proven before the original crime, the most important is that the money laundering elements have been fulfilled. The third opinion is that at least the original crime is proven together with the money laundering. With regard to this matter, based on Article 69 of the 2010 PPTPPU Law, the law says that the money laundering does not need to be proven first but the intention is that the "original crime" does not need to be proven first in a stand-alone court decision. ${ }^{40}$

On the other hand, according to Manthovani ${ }^{41}$, the original crime of money laundering does not need to be proven first. This is because the intention and the purpose of money laundering criminalization is to save assets resulted from criminal offenses. The delay to prove the original criminal act first can make the potential of the defendant to hide assets. The PPTPPU Law philosophy is to follow the assets. This law was formulated so that law enforcement officials could trace, freeze, confiscate, or return assets resulted from crime to the state or the party affected. However, evidentiary of money laundering must trace, reveal, or even prove that the money, which is the object of the money laundering, is the proceeds of crime. If the results of the crime are not revealed, there can be elements of the article that are not fulfilled, namely the element of "assets resulted from criminal acts".

In the case of Hendra Widjaja, the public prosecutor did not indict the original criminal act. The indictment was intended to the money laundering case. The public prosecutor includes legal facts about the defendant's embezzlement in the indictment. This is understandable because in one of the elements of the money laundering article there is an element of "assets resulted from criminal act", which inevitably requires a legal fact to be stated in the indictment.

To prove the element of 'assets resulting from criminal acts', there are several ways that the public prosecutor can do. One of them is by looking at the profile of the defendant. In the indictment, the public prosecutor must be able to describe the financial profile of the defendant, such as his monthly income, the sources of income, possibility of other incomes, and acceptance of grant for certain items, etc. It is to assess whether the assets of the defendant have a correlation with his legal income.

In handling the case of Hendra Widjaja, the public prosecutor, in the indictment, outlines the time when the defendant worked at PT. Driver's License,

Indictment, loc.cit.

lbid.

41 interview with Reda Manthovani Manthovani, General Assistant of the Attorney General of the Republic of Indonesia, on June 3, 2019, took place at the Indonesian Attorney General's Office. 
his monthly income, the positions he holds, numbers of assets he accumulated during the time, and other jobs at the time he works for PT SIM. This description enabled the public prosecutor to calculate whether the defendant's assets correspond to his legal income or not. Based on the public prosecutors' view, the defendant's assets are far greater than his legal income. After the tracing, it was strongly suspected that the defendant obtained the assets from the embezzlement that he committed at PT SIM.

Furthermore, the mechanism to prove criminal offenses is very dependent on the form of indictment and the prosecution. If the money laundering case and the criminal case were combined in one indictment, the public prosecutor only needed to prove the first indictment before proceeding with the second indictment, which is the money laundering.

If the indictment was made in a single form, only the money laundering, without indicting the original criminal offense, then the original criminal offense can be proven by an element of the article of money laundering. In the case of Hendra Widjaja, the public prosecutor made a single indictment and proved that the crime was carried out on one of the elements of the money laundering, namely "assets that are known to or supposedly are the result of criminal acts". The public prosecutor outlined article 374 of the Criminal Code in the elements of the money laundering article and subsequently analyzed each element by connecting the major premise (rules/elements of the article) to the minor premise (legal facts) and then made a conclusion. It must be stressed that when proving this element, the public prosecutor must be able to present legal facts that are supported by at least two valid evidences to prove the original criminal offense from the offense charged. Therefore, since the preparation of the indictment, the public prosecutor must have outlined the legal facts of the defendant's original crime.

\section{Conclusions}

Based on the principle of legality of formal law, which emphasizes the principles of lex scripta, lex stricta, and lex certa, the implementation of trial in absentia on conventional criminal acts cannot be implemented. This is because the PPTPPU Law does not regulate the application of trial in absentia for money laundering case originating from conventional criminal case. On the other hand, the Criminal Procedure Code, as a procedural law for conventional criminal acts in the Criminal Code, requires the presence of defendant in the trial process. Therefore, law enforcers, including public prosecutor, are not permitted to take undue to law actions or outside the undue process required by law.

Based on the principle of due process of law, the prosecution strategy to handle money laundering case that is originated from conventional criminal acts are as follows. Firstly, prosecution mechanisms for two cases of money laundering and original crime must be carried out separately. Secondly, public prosecutor must delay the trial request for original criminal acts to the court until defendant is 
found. Thirdly, indictment must be compiled in a single form and the article charged is only the money laundering articles. Fourthly, even though the original criminal act was not charged, indictment must clearly draw the description of legal facts of the criminal act to determine the crime that result assets. Fifthly, public prosecutor can prove the legal facts of the original crime in one of the elements of the money laundering, namely the element of 'assets resulted from the crime'.

\section{References}

\section{Books}

Andi Hamzah, Hukum Acara Pidana Indonesia, Sinar Grafika, Jakarta, 2009.

Andi Hamzah, Pre-Trial Justice Discretionary Justice Dalam KUHAP Berbagai Negara, Sinar Grafika, Jakarta, 2015.

Barda Nawawi Arief, Kapita Selekta Hukum Pidana tentang Sistem Peradilan Pidana Terpadu (integrated criminal justice system), Badan Penerbit UNDIP, Semarang, 2006.

Eddy O.S Hiariej, Teori \& Hukum Pembuktian, Penerbit Erlangga, Jakarta, 2012.

Marwan Effendy, Peradilan In Absentia dan Koneksitas, Timpani Publishing, Jakarta, 2010.

Muhammad Yusuf, Kapita Selekta TPPU: Kumpulan Pembahasan Mengenai Isu-Isu Terkini dan Menarik, PPATK, Jakarta, 2016.

Reda Manthovani, R. Narendra Jatna, Rezim Anti Pencucian Uang dan Perolehan Hasil Kejahatan Indonesia, Malibu, Jakarta, 2012.

Romli Atmasasmita, Globalisasi dan Kejahatan Bisnis, Kecana Prenada Media Group, Jakarta, 2010.

Sudarto, Kapita Selekta Hukum Pidana, PT. Alumni, Bandung, 2006.

Sutherland, Edwin H., White Collar Crime, Yale University, Binghamton, 1983.

Yenti Garnasih, Penegakan Anti Pencucian Uang dan Permasalahannya di Indonesia, PT. Raja Grafindo Persada, Jakarta, 2015.

Yesmil Anwar dan Adang, Sistem Peradilan Pidana: Konsep, Komponen, dan Pelaksanaan dalam Penegakan Hukum di Indonesia, Widya Padjadjaran, Bandung, 2009.

Yudi Kristiana, Pemberantasan Tindak Pidana Pencucian Uang Perspektif Hukum Progresif, Thafamedia, Jakarta, 2015.

\section{Other Documents}

Anthon F Susanto, "Membangun Sistem Peradilan Pidana Indonesia," Jurnal IImu Hukum Litigasi-Unpas, Vol. 3, No. 1, 2002.

Eddy OS Hiariej, "Keterangan Ahli pada Persidangan Mahkamah Konstitusi dalam perkara Sengketa Hasil PHPU Pilpres Tahun 2019", Kompas TV, accessed on June 2019. 
Elsa Emiria Leba, "Berkejaran dengan Kelicikan Pencucian Uang", https://kompas.id/baca/polhuk/2018/12/22/berkejaran-dengan-kelicikanpencucian-uang, accessed on January 2019.

Elsa Emiria Leba, "Tindak Pidana Pencucian Uang Lintas Negara Semakin Marak", Koran Kompas 31 $1^{\text {st }}$ October 2018.

Jimly Asshiddiqie, "Prinsip Pokok Negara Hukum," http://www.jimly.com/pemikiran/view/11, accessed on February 2019.

Laporan Wawancara dengan Reda Manthovani, Asisten Umum Jaksa Agung RI, pada tanggal 3 Juni 2019 bertempat di Kejaksaan Agung.

Laporan Wawancara dengan Sandhy Handika, Kepala Seksi Tindak Pidana Umum Kejaksaan Negeri Kabupaten Bekasi tanggal 1 Juni 2019 bertempat di Kejaksaan Negeri Kabupaten Bekasi.

Shidarta, "Asas Legalitas", https://business-law.binus.ac.id/2016/02/02/asaslegalitas/, accessed on June 2019.

Yohana Artha Uly, "PPATK: Setiap Hari Ada 100.000 Laporan Kasus Pencucian Uang", https://economy.okezone.com/read/2018/12/18/20/1992816/ppatksetiap-hari-ada-100-000-laporan-kasus-pencucian-uang, accessed on January 2019.

\section{Law Documents}

Law Number 8 of 1981 on the Criminal Procedure Code [Undang-Undang Nomor 8 Tahun 1981 Tentang Kitab Undang-Undang Hukum Acara Pidana].

Law Number 15 of 2003 on the Establishment of Government Regulation in Lieu of the Law Number 1 of 2002 on the Eradication of Terrorism Crimes Act, as amended by the Law Number 5 of 2018 on the Amendment to the Law Number 15 of 2003 on the Establishment of Government Regulation in Lieu of the Law Number 1 of 2002 on Eradication of the Criminal Acts of Terrorism into Laws (the Terrorism Act) [Undang-Undang Nomor 15 Tahun 2003 tentang Penetapan Peraturan Pemerintah Pengganti Undang-Undang Nomor 1 Tahun 2002 tentang Pemberantasan Tindak Pidana Terorisme Menjadi Undang-Undang, sebagaimana telah diubah dengan Undang-Undang Nomor 5 Tahun 2018 tentang Perubahan Undang-Undang Nomor 15 Tahun 2003 tentang Penetapan Peraturan Pemerintah Pengganti Undang-Undang Nomor 1 Tahun 2002 tentang Pemberantasan Tindak Pidana Terorisme Menjadi Undang-Undang (UU Terorisme)].

Law Number 18 of 2013 on the Prevention and the Eradication of Forest Destruction [Undang-Undang Nomor 18 Tahun 2013 tentang Pencegahan dan Pemberantasan Perusakan Hutan (UU PPPH)].

Law Number 31 of 1999 on Eradication of Corruption Acts as amended by the Law Number 20 of 2001 on the Amendment to the Law Number 31 of 1999 on Eradication of Corruption (the PTPK Law) [Undang-Undang Nomor 31 Tahun 1999 tentang Pemberantasan Tindak Pidana Korupsi sebagaimana telah diubah 
dengan Undang-Undang Nomor 20 Tahun 2001 tentang Perubahan Atas Undang-Undang Nomor 31 Tahun 1999 tentang Pemberantasan Tindak Pidana Korupsi (UU PTPK)].

Law Number 31 of 2004 on the Fisheries as amended by the Law Number 45 of 2009 on the Amendment to the Law Number 31 of 2004 on Fisheries (Fisheries Law) [Undang-Undang Nomor 31 Tahun 2004 tentang Perikanan sebagaimana telah diubah dengan Undang-Undang Nomor 45 Tahun 2009 tentang Perubahan Atas Undang-Undang Nomor 31 Tahun 2004 tentang Perikanan (UU Perikanan)].

Law Number 15 of 2002 on Money Laundering, as amended by the Law Number 25 of 2003 on the Amendment to the Law Number 15 of 2002 on Crime Acts of Money Laundering, in conjunction with Article 65, Paragraph (1), of the Criminal Code, in conjunction with Article 95 of the Law Number 8 of 2010 on the Prevention and the Eradication of Money Laundering Crimes [UndangUndang Nomor 15 Tahun 2002 tentang Tindak Pidana Pencucian Uang, sebagaimana telah diubah dengan Undang-Undang Nomor 25 Tahun 2003 tentang Perubahan Undang-Undang No.15 tahun 2002 tentang Tindak Pidana Pencucian Uang].

Law Number 8 of 2010 on the Prevention and Eradication of Money Laundering Crimes [Undang-Undang Nomor 8 Tahun 2010 tentang Pencegahan dan Pemberantasan Tindak Pidana Pencucian Uang]

The Decree of the Constitutional Court Number 77/PUU-XII/2014 [Putusan Mahkamah Konstitusi Nomor 77/PUU-XII/2014].

The Decision of the Central Jakarta State Court Number 339/PID.B/2010/PN.JKT.PST, Jakarta, 2010 [Putusan Pengadilan Negeri Jakarta Pusat Nomor 339/PID.B/2010/PN.JKT.PST, Jakarta, 2010].

Interim Decision of the Judge of the Bekasi District Court Number 392/Pid. Sus/2017/PN dated 18 July 2017 [Putusan Sela Majelis Hakim Pengadilan Negeri Bekasi Nomor 392/Pid. Sus/2017/PN tanggal 18 Juli 2017].

Circular of the Attorney General of the Republic of Indonesia Number: SE004/J.A/11/1993 on the Making of Indictment (SEJA Indictment) [Surat Edaran Jaksa Agung Republik Indonesia Nomor: SE-004/J.A/11/1993 Tentang Pembuatan Surat Dakwaan (SEJA Surat Dakwaan)]

Order of the Head of the Bekasi District Prosecutor Office Regarding the Appointment of a Public Prosecutor to Resolve Criminal Case Number: PRINT.1119/O.2.35/Euh.2/3/2017 dated March 23, 2018 [Surat Perintah Kepala Kejaksaan Negeri Kabupaten Bekasi Perihal Penunjukan Penuntut Umum Untuk Menyelesaikan Perkara Pidana Nomor: PRINT.1119/O.2.35/Euh.2/3/2017 tanggal 23 Maret 2018].

Prosecutor's Register Number: PDM- 276/CKR/05/2017 on October 19, 2017 [Surat Tuntutan Penuntut Umum Register Perkara Nomor PDM- 276/CKR/05/2017 tanggal 19 Oktober]. 